\title{
INVESTASI DAN PASAR MODAL, MEMAHAMI PERANAN BANK INDONESIA, BAPEPAM-LK, DAN OTORITAS JASA KEUANGAN DALAM LINGKUNGAN PASAR MODAL
}

\author{
Oleh \\ Raendhi Rahmadi*)
}

\section{Abstrak}

Pasar Modal Indonesia tumbuh dengan sangat baik dan menawarkan tingkat pengembalian keuntungan yang besar namun juga dalam hal ini berlaku sebaliknya dengan tingkat kerugian yang besar pula, maka itu di butuhkan aturan yang jelas dan tepat baik dalam pengaturannya juga dari pengawasannya, di Indonesia pasar modal diatur melalui lembaga lembaga yang telah di tunjuk untuk melakukan itu diantaranya adalah Bank Indonesia, BAPEPAM-LK dan kini dipusatkan pada Otoritas Jasa Keuangan yang semuanya memiliki kewenangan yang berbeda sehingga sangat penting untuk mengetahui fungsinya masingmasing serta batasan kewenangan masing-masing dalam mengatur dan mengawasi Pasar Modal Indonesia.

\section{Kata Kunci : Fungsi, Batasan Kewenangan}

\section{A. PENDAHULUAN}

Dalam melihat permasalahan perekonomian di suatu negara, instansi yang bertanggung jawab mengenai hal ekonomi lazimnya berada di bawah eksekutif yang membidangi perekonomian, namun ketika pembahasannya adalah masalah kekayaan dan keuangan maka yang menjadi pemegang tanggung jawab berada di sisi eksekutif bidang keuangan. Namun banyak contoh dari berbagai negara dimana keuangan tidak saja diatur oleh lembaga eksekutif keuangan namun juga terjadi pembagian kewenangan dimana penerapan keuangan dalam pengertian umum diserahkan pada bank central, sedang hal yang terkait dengan pengaturan kebijakan ekonomi berada di bawah Kementerian Keuangan.

Kementrian keuangan di Indonesia memiliki otoritas yang luas dalam mengatur keuangan dan melakukan kebijakan moneter dan salah satu lininya adalah

*) Penulis adalah Dosen Fakultas Hukum

Universitas Islam Syekh Yusuf pada pengawasan pasar modal di Indonesia. Pasar modal sebagai suatu lembaga yang dibuat secara khusus di Indonesia memiliki peranan yang sangat strategis sebagai suatu fasilitas dan alat bagi masyarakat untuk dapat bertransaksi dan memudahkannya dalam melakukan perdagangan instrumen investasi yang diantaranya adalah saham dan instrumen lainnya sebagai sarana investasi bagi masyarakat.

Pengawasan ini ditangani oleh suatu lembaga khusus yang dinamakan sebagai BAPEPAM-LK yang merupakan singkatan dari Badan Pengawasan Pasar Modal dan Lembaga Keuangan, badan ini merupakan suatu lembaga yang berada dibawah kementrian Keuangan Republik Indonesia. Tugas dari BAPEPAM ini adalah membuat aturan, mengawasi dan menegakkan regulasi dalam bidang pasar modal di Indonesia yang akan di jabarkan dan di jelaskan dalam pembahasan dalam tulisan ini dengan lebih mendalam. 
Bapepam sebagai suatu lembaga yang mengawasi pasar modal ini telah berubah sejak tahun 2012 yang secara formal akan menggantikan tugas BAPEPAM-LK pada tanggal 31 Desember 2012 dengan berdasar pada lahirnya undang-undang nomor 21 tahun 2012 tentang OJK (Otoritas Jasa Keuangan) maka dengan berlakunya undang undang ini resmi OJK yaitu Otoritas Jasa Keuangan bertugas menggantikan tugas BAPEPAM-LK menjadi Lembaga yang bertanggung jawab dalam bidang jasa keuangan. OJK memiliki kewenangan yang lebih luas dibandingkan dengan kewenangan yang dimiliki oleh BAPEPAM-LK yang nantinya akan dibahas, karena kewenangan yang dimiliki oleh OJK meliputi tugas dan wewenang yang tadinya diberikan kepada sebagaian kementrian keuangan yang membawahi BAPEPAM-LK dan ditambah dengan kewenangan lainnya yang semulanya menjadi kewenangan dari Bank Indonesia.

Dalam tulisan ini kita akan membahas mengenai tiga hal ini, yaitu mengenai Bank Indonesia, BAPEPAM-LK dan OJK sebagai mata pembahasan utama dalam tulisan ini agar dapat lebih dikenal dan sekaligus memberikan gambaran bagi pasar modal, khususnya pasar modal Indonesia.

Sekilas bila kita membahas mengenai pasar modal di Indonesia, maka kita tidak dapat menghindar dari sejarah pasar modal itu sendiri di Indonesia, pasar modal di Indonesia memang baru ada sejak pasca kemerdekaan di zaman pemerintahan presiden pertama Republik Indonesia yaitu pada masa Bung Karno, namun sejarah juga mencatat bahwa keberadaan pasar modal Multi Nasional Pertama di dunia juga bersentuhan dengan sejarah Indonesia keberadaannya, karena perusahaan yang sahamnya dijual di pasar tersebut adalah suatu perusahaan yang berkedudukan di Indonesia yaitu suatu perusahaan dagang yang sangat mahsyur di jamannya yang bernama VOC yaitu Vereenigde Oostindische Compagnie yang merupakan sebuah perusahaan belanda yang mampu memonopoli perdagangan rempah dunia di kala itu, khususnya pada pasar internasional lebih dari tiga abad lamanya.

\section{B. PEMBAHASAN}

Pada tulisan ini perlu di jelaskan mengenai Pasar Modal itu sendiri dan akan lebih diarahkan pada pembahasan atas fungsi serta kewenangan lembaga yang memiliki andil tanggung jawab untuk mengatur dan mengawasi pasar modal tersebut dapat berjalan dengan baik dan tepat.

Bila kita melihat pada Undang undang nomor 8 tahun 1995 tentang pasar modal maka kita akan mendapati pada pasal 1 ayat 13 yang menyebutkan bahwa "pasar modal adalah kegiatan yang bersangkutan dengan Penawaran Umum dan perdagangan Efek, Perusahaan Publik yang berkaitan dengan Efek yang diterbitkannya, serta lembaga dan profesi yang berkaitan dengan Efek". Penjelasan ini mungkin terlihat kurang memberikan pemahaman yang sederhana maka dapat kita sederhanakan dengan menyebutkan bahwa pasar modal adalah pasar yang telah diatur sedemikian rupa secara terorganisir dimana instrumen yang di perdagangkan di dalamnya memuat instrumen investasi yang menjadi modal bagi emiten berupa obligasi, option, saham, warrant dan lainnya yang dilakukan dengan melibatkan perantara, instansi, profesi tertentu berdasarkan aturan yang berlaku disebuah negara. Melalui penafsiran diatas maka kita dapat menarik sedikit gambaran mengenai apa yang di maksud dengan pasar modal. Berlanjut melihat hal yang dimaksud dengan instrumen investasi yang disebutkan di atas adalah suatu instrumen yang berupa 
efek, dimana Efek adalah surat berharga, yaitu surat pengakuan utang, surat berharga komersial, saham, obligasi, tanda bukti utang, Unit Penyertaan kontrak investasi kolektif, kontrak berjangka atas Efek, dan setiap derivatif dari Efek. Maka gambaran ini telah menjelaskan mengenai apa objek yang dimaksud dalam instrumen investasi yang di maksudkan dalam pengertian di atas.

Sebagai suatu pasar khusus yang disediakan oleh negara untuk memenuhi dan dimaksudkan untuk mengcover transaksi permodalan yang ada di Indonesia maka Pasar modal diatur secara ketat dengan meletakkan lembaga-lembaga tertentu untuk menjadi regulator sekaligus pengawas yang bertanggung jawab untuk menangani hal ini dengan lebih spesifik/detail. Lembaga yang dimaksud adalah Bank Indonesia sebagai Bank Sentral yang ada di Indonesia, lalu BAPEPAM-LK yaitu satu badan yang berada di bawah Kementrian Keuangan dan OJK sebagai badan baru yang menjadi pewaris kewenangan yang dimiliki oleh BAPEPAM-LK beserta beberapa kewenangan tambahan lainnya yang didapatkan dari kewenangan instansi lainnya selain BAPEPAM-LK itu sendiri.

Bagaimana peranan Bank Indonesia, BAPEPAM-LK dan OJK dalam perkembangan pasar modal di Indonesia?

Ketika kita ingin membahas mengenai peranannya maka baiknya terlebih dahulu kita memahami tujuan, tugas, fungsi dan wewenang masing-masing dari Bank Indonesia, BAPEPAM-LK dan OJK terlebih dahulu, yang kemudian ditarik kaitannya dengan penerapan pasar modal, yaitu sebagaimana yang dapat dipaparkan sebagai berikut :

\section{Bank Indonesia}

Ketika kita ingin membahas mengenai Tujuan, Tugas dan Fungsi Bank Indonesia maka Tujuan dari Bank Indonesia adalah mencapai dan memelihara kestabilan nilai rupiah, hal ini tertuang dalam pasal 7 Undang-undang No. 23 Tahun 1999 tentang Bank Indonesia dimana kita tidak akan terlepas dari konsep pemahaman menganai tiga pilar dan tugas Bank Indonesia sebagaimana yang di sebutkan pada pasal 8 Undangundang tersebut, hal ini meliputi:

- Menetapkan dan Melaksanakan Kebijakan Moneter

- Mengatur dan Menjaga Kelancaran Sistem Pembayaran

- Mengatur dan Mengawasi Perbankan di Indonesia

Ketiga tiga pilar ini merupakan tugas dan fungsi utama dari bank Indonesia yang dapat diterangkan secara sederhana sebagai berikut:

Fungsi Menetapkan dan Melaksanakan Kebijakan Moneter adalah fungsi menentukan dan menetapkan suku bunga pada bank dan surat-surat berharga, yang tujuannya ada-lah untuk mengendalikan tingkat inflasi dan/atau deflasi sehingga men-ciptakan stabilitas dalam moneter negara namun hal ini tidak sese-derhana itu melainkan lebih kompleks dengan kebijakan kebijakan yang sesuai dan mengikuti dinamisnya keadaan yang ada.

Fungsi Mengatur dan Menjaga Kelancaran Sistem Pembayaran adalah fungsi bank sentral dalam melakukan sinkronasi pembayaran yang begitu banyak macamnya untuk memuluskan semua model pembayaran tersebut sehingga pembayaran yang dilakukan satu dan lainnya menjadi lancar dan berjalan dengan baik, hal ini juga terkait dengan penerbitan uang dan sebagainya sesuai dengan yang dimaksud dengan Undangundang tentang Bank Indonesia tersebut. Fungsi mengatur dan menjaga ini berarti juga mengatur terhadap transaksi kliring antar bank yang ada pada bank agar Pembayaran yang dilakukan dapat berjalan lancar dan baik ini memiliki efek positif berantai pada kepercayaan mata 
uang dan hal ini dapat meningkatkan kepercayaan terhadap mata uang yang dijaga oleh Bank Indonesia sebagai Bank Sentral yang bertugas menjaga stabilitas nilai rupiah.

Fungsi Mengatur dan Mengawasi Perbankan di Indonesia adalah fungsi Bank Indonesia yang dengan jelas disampaikan pada pasal 24 yang menyatakan bahwa "Dalam rangka melaksanakan tugas sebagaimana dimaksud dalam Pasal 8 huruf c, Bank Indonesia menetapkan peraturan, memberikan dan mencabut izin atas kelembagaan dan kegiatan usaha tertentu dari Bank, melaksanakan pengawasan Bank, dan mengenakan sanksi terhadap Bank sesuai dengan ketentuan perundang-undangan." Hal ini bermakna jelas bahwa Bank Indonesia adalah Regulator sekaligus Pengawas terhadap Perbankan yang ada di Indonesia.

Mengaitkan kewenangan ini dalam sudut pandang pasar modal maka, pasar modal sebagai salah satu bagian dari pasar uang, dengan kepentingan untuk mendapatkan modal bagi emiten dari masyarakat, maupun tran-saksi efek antara masyarakat dengan masyarakat, maka memiliki keterkait-an dalam sisi keuangan yang mana menjadi ranah domain dari kewenangan Bank Indonesia, dimana sebelumnya setiap kegiatan usaha yang memiliki kegiatan menerima atau meng-himpun dana dari masyarakat masuk dalam ranah kegiatan usaha bank atau merupakan bagian dari bank itu sendiri, yang kemudian pengawasannya sepanjang belum dibentuk menjadi ranah penagwasan dari Bank Indonesia. Hal ini membuat Bank Indonesia memiliki kewenagan lebih secara temporarikal. Selain itu juga dengan adanya peranan dari lembaga Bank Kostudian dalam memberi fasilitas dalam transaksi pasar modal membuat Bank Indonesia memiliki kewenangan dalam mengawasi bank yang terdaftar sebagai Bank Kostudian yang mengelola dan menyimpan dana Nasabah yang biasa di sebut RDN (Rekening Dana Nasabah) dalam Pasar Modal.

\section{BAPEPAM-LK}

Membahas menganai tujuan, tugas dan Fungsi BAPEPAM maka kita lihat terlebih dahulu awal pengenalan BAPEPAM-LK ini awal kalinya di perkenalkan berdasarkan KepPres 53 tahun 1990 tentang Pasar Modal, dalam Kepres ini diperkenalkan suatu lembaga yang melakukan pengawasan pasa pasal 2 ayat 2 yang bertanggung jawab terhadap menteri. Dapun Tugasnya disebutkan dalam pasal 3 ayat 2 yang berbunyi “

(2) BAPEPAM mempunyai tugas:

a. mengikuti perkembangan dan mengatur pasar modal sehingga Efek dapat ditawarkan dan diperdagangkan secara teratur, wajar, dan efisien serta melindungi kepentingan pemodal dan masyarakat umum;

b. melakukan pembinaan dan pengawasan terhadap lembaga-lembaga sebagaimana dimaksud dalam BAB III, BAB IV, BAB V dan BAB VI dan BAB VII; dan

c. memberikan pendapat kepada Menteri mengenai pasar modal."

Adapun BAB III, BAB IV, BAB V BAB VI dan BAB VII yang dimaksud diatas adalah :

- BAB III : Bursa Efek Dan Lembaga Kliring Penyelesaian Dan Penyimpanan

- BAB IV : Reksa Dana

- BAB V : Perusahaan Efek Dan Perorangan

- BAB VI : Lembaga Penunjang Pasar Modal

- BAB VII : Profesi Penunjang Pasar Modal

Yang kemudian fungsinya di tentukan dalam KMK (Keputusan Menteri Keuangan) yaitu pada Pasal 3 Keputusan Menteri Keuangan RI Nomor 
503/KMK.01/1997 Tentang Organisasi dan Tata Kerja Badan Pengawas Pasar Modal (BAPEPAM-LK) ${ }^{1}$ sebagai berikut :

1. menyusun peraturan di bidang pasar modal;

2. menegakkan peraturan di bidang pasar modal;

3. pembinaan dan pengawasan terhadap pihak yang memperoleh izin usaha, persetujuan dan pendaftaran dari Bapepam dan pihak lain yang bergerak di pasar modal;

4. menetapkan prinsip keterbukaan perusahaan bagi emiten dan perusahaan publik;

5. Penyelesaikan keberatan yang diajukan oleh pihak yang dikenakan sanksi oleh bursa efek, Lembaga Kliring dan Penjaminan (LKP), dan Lembaga Penyimpanan dan Penyelesaian (LPP);

6. menetapkan ketentuan akuntansi di bidang pasar modal;

7. pengamanan teknis pelaksanaan tugas pokok Bapepam sesuai dengan kebijakan Menteri Keuangan dan berdasarkan peraturan perundangundangan yang berlaku.

Adapun kewenangan yang di miliki oleh BAPEPAM-LK adalah sebagaimana yang disampaikan dalam Pasal 5 Undangundang Nomor 8 tahun 1995 tentang Pasar Modal yang berbunyi : "Dalam melaksanakan ketentuan sebagaimana dimaksud dalam Pasal 3 dan Pasal 4, Bapepam berwenang untuk:

a. memberi:

1). izin usaha kepada Bursa Efek, Lembaga Kliring dan Penjaminan, Lembaga Penyimpanan dan Penyelesaian, Reksa Dana, Perusahaan Efek, Penasihat Investasi, dan Biro Administrasi Efek;

\footnotetext{
${ }^{1}$ Iswi Hariyani, Buku Pintar Hukum Bisnis Pasar Modal, hal 14
}

2). izin orang perseorangan bagi Wakil Penjamin Emisi Efek, Wakil Perantara Pedagang Efek, dan Wakil Manajer Investasi; dan

3). persetujuan bagi Bank Kustodian. b).mewajibkan pendaftaran Profesi Penunjang Pasar Modal dan Wali Amanat;

c). menetapkan persyaratan dan tata cara pencalonan dan memberhentikan untuk sementara waktu komisaris dan atau direktur serta menunjuk manajemen sementara Bursa Efek, Lembaga Kliring dan Penjaminan, serta Lembaga Penyimpanan dan Penyelesaian sampai dengan dipilihnya komisaris dan atau direktur yang baru;

d).menetapkan persyaratan dan tata cara Pernyataan Pendaftaran serta menyatakan, menunda, atau membatalkan efektifnya Pernyataan Pendaftaran;

e). mengadakan pemeriksaan dan penyidikan terhadap setiap Pihak dalam hal terjadi peristiwa yang diduga merupakan pelanggaran terhadap Undang-undang ini dan atau peraturan pelaksanaannya.

f). mewajibkan setiap Pihak untuk:

1).menghentikan atau memperbaiki iklan atau promosi yang berhubungan dengan kegiatan di Pasar Modal; atau

2).mengambil langkah-langkah yang diperlukan untuk mengatasi akibat yang timbul dari iklan atau promosi dimaksud.

g). melakukan pemeriksaan terhadap:

1).setiap Emiten atau Perusahaan Publik yang telah atau diwajibkan menyampaikan Pernyataan Pendaftaran kepada Bapepam; atau

2).Pihak yang dipersyaratkan memiliki izin usaha, izin orang perseorangan, persetujuan, atau 
pendaftaran profesi berdasarkan Undang-undang ini.

h. menunjuk Pihak lain untuk melakukan pemeriksaan tertentu dalam rangka pelaksanaan wewenang Bapepam sebagaimana dimaksud dalam huruf g;

i. mengumumkan hasil pemeriksaan;

j. membekukan atau membatalkan pencatatan suatu Efek pada Bursa Efek atau menghentikan Transaksi Bursa atas Efek tertentu untuk jangka waktu tertentu guna melindungi kepentingan pemodal;

k. menghentikan kegiatan perdagangan Bursa Efek untuk jangka waktu tertentu dalam hal keadaan darurat;

1. memeriksa keberatan yang diajukan oleh Pihak yang dikenakan sanksi oleh Bursa Efek, Lembaga Kliring dan Penjaminan, atau Lembaga Penyimpanan dan Penyelesaian serta memberikan keputusan membatalkan atau menguatkan pengenaan sanksi dimaksud;

m. menetapkan biaya perizinan, persetujuan, pendaftaran, pemeriksaan, dan penelitian serta biaya lain dalam rangka kegiatan Pasar Modal;

n. melakukan tindakan yang diperlukan untuk mencegah kerugian masyarakat sebagai akibat pelanggaran atas ketentuan di bidang Pasar Modal;

o. memberikan penjelasan lebih lanjut yang bersifat teknis atas Undangundang ini atau peraturan pelaksanaannya;

p. menetapkan instrumen lain sebagai Efek selain yang telah ditentukan dalam Pasal 1 angka 5; dan

q. melakukan hal-hal lain yang diberikan berdasarkan Undangundang ini. ${ }^{\text {" }}$

\footnotetext{
${ }^{2}$ Pasal 5 Undang-undang Nomor 8 tahun 1995 tentang Pasar Modal
}

Seiring berjalannya waktu perkembangan pemerintahan dan nomenklatur terjadi diberbagai lini dimana untuk pasar modal dirasa perlu suatu badan yang lebih independen dan mampu untuk menjawab kebutuhan dan perkembangan pasar modal di Indonesia, hal ini merupakan hasil study yang cukup panjang dimana mencontoh dari berbagai negara, ada yang menyatakan bahwa sebaiknya lembaga keuangan di awasi oleh lembaga tunggal, namun ada juga pendapat lainnya yang menyatakan bahwa lebih baik diawasi oleh beberapa lembaga/institusi, bila di bandingkan kita dapat mengambil contoh dari Financial Supervisory Authority (FSA) di Inggris, sedangkan di Amerika Serikat industri keuangan diawasi oleh beberapa institusi, diantaranya adalah SEC (Securities and Exchange Comission), Federal Reserve (The Fed), FDIC (Federal Deposit Insurance Corporation), dan OCC (Office of The Comptroller of The Currency). Namun demikian tidak ada salahnya dengan kedua hal tersebut hanya saja Indonesia perlu menyesuaikan kearah mana yang paling cocok bagi pasar modal yang ada di Indonesia.

Hingga pada tahun 2011 terbitlah suatu lembaga yang ditugaskan menjadi lembaga yang independen dan dikhususkan untuk menjadi pengawas dan regulator bagi lembaga keuangan secara keseluruhan yang termasuk pasar modal di dalamnya.

Meski undang-undang tentang Otoritas Jasa Keuangan diterbitkan pada tahun 2011 namun mulai bekerjanya OJK tidak serta merta di lakukan pada tahun tersebut karena ada masa transisi yang dilakukan hingga Desember 2012 sebagaimana disebutkan dalam Pasal 55 tentang Peralihan, dimana momen awal mulainya OJK menjalankan tugasnya adalah pada tanggal 31 Desember 2012. Sehingga pada saat itu beralihlah kewenagan BAPEPAM-LK kepada OJK, 
Namun demikian ada beberapa kewenangan dari BAPEPAM-LK yang tetap dijalankan oleh kementrian keuangan yang tidak beralih kepada $\mathrm{OJK}^{3}$, yaitu kewenangan sebagai berikut :

a. Fungsi Pengaturan Tertentu;

b. Fungsi Kesekretariatan Forum Koordinasi Stabilitas Sektor Keuangan;

c. Fungsi Hubungan Internasional;

d. Penanganan dokumen dan permasalahan eks UP3 (Unit Pelaksana Penjaminan Pemerintah);

e. Perizinan dan Pengawasan Aktuaris;

f. Pembinaan atas jaminan sosial dan dana pensiun PNS saat ini menjadi salahsatu tugas Biro Dana Pensiun;

g. Pelaksanaan UU 33 tahun 1964 tentang Dana Pertanggung Jawaban Wajib Kecelakaan Penumpang dan UU 34 tahun 1964 tentang Dana Pertanggung Jawaban Wajib Kecelakaan Lalu Lintas Jalan;

h. BPJS.

\section{Otoritas Jasa Keuangan}

Mengenal Otoritas Jasa Keuangan, melihat pengertiannya lembaga OJK adalah lembaga yang independen dan bebas dari campur tangan pihak lain, yang mempunyai fungsi, tugas, dan wewenang pengaturan, pengawasan, pemeriksaan, dan penyidikan sebagaimana dimaksud dalam UndangUndang No 21 tahun 2011 tentang Otoritas Jasa Keuangan.

Dalam Undang-undang OJK pada Pasal 4 disampaikan bahwa Tujuan dari dibentuknya OJK, adalah "agar keseluruhan kegiatan di dalam sektor jasa keuangan:

i. terselenggara secara teratur, adil, transparan, dan akuntabel;

\footnotetext{
${ }^{3}$ https: / /www.sahamok.com/pasarmodal/tugas-dan-fungsi-bapepam-lk-pindahke-ojk/
}

j. mampu mewujudkan sistem keuangan yang tumbuh secara berkelanjutan dan stabil; dan

k. mampu melindungi kepentingan Konsumen dan masyarakat."

Dimana dalam pasal 5 disebutkan, "OJK berfungsi menyelenggarakan sistem pengaturan dan pengawasan yang terintegrasi terhadap keseluruhan kegiatan di dalam sektor jasa keuangan."

Pasal 6 menyebutkan bahwa "OJK melaksanakan tugas pengaturan dan pengawasan terhadap:

a. kegiatan jasa keuangan di sektor Perbankan;

b. kegiatan jasa keuangan di sektor Pasar Modal; dan

c. kegiatan jasa keuangan di sektor Perasuransian, Dana Pensiun, Lembaga Pembiayaan, dan Lembaga Jasa Keuangan Lainnya."

Sedangkan untuk kewenangan yang di miliki OJK kita dapat melihatnya pada pasal 7, 8 dan 9 pada Undang-undang Otoritas Jasa Keuangan yaitu :

\section{"Pasal 7}

Untuk melaksanakan tugas pengaturan dan pengawasan di sektor Perbankan sebagaimana dimaksud dalam Pasal 6 huruf a, OJK mempunyai wewenang:

a. pengaturan dan pengawasan mengenai kelembagaan bank yang meliputi:

1. perizinan untuk pendirian bank, pembukaan kantor bank, anggaran dasar, rencana kerja, kepemilikan, kepengurusan dan sumber daya manusia, merger, konsolidasi dan akuisisi bank, serta pencabutan izin usaha bank; dan

2. kegiatan usaha bank, antara lain sumber dana, penyediaan dana, produk hibridasi, dan aktivitas di bidang jasa;

b. pengaturan dan pengawasan mengenai kesehatan bank yang meliputi: 
1. likuiditas, rentabilitas, solvabilitas, kualitas aset, rasio kecukupan modal minimum, batas maksimum pemberian kredit, rasio pinjaman terhadap simpanan, dan pencadangan bank;

2. laporan bank yang terkait dengan kesehatan dan kinerja bank;

3. sistem informasi debitur;

4. pengujian kredit (credit testing); dan

5. standar akuntansi bank;

c. pengaturan dan pengawasan mengenai aspek kehati-hatian bank, meliputi:

1. manajemen risiko;

2. tata kelola bank;

3. prinsip mengenal nasabah dan anti pencucian uang; dan

4. pencegahan pembiayaan terorisme dan kejahatan perbankan; dan

d. pemeriksaan bank.

\section{Pasal 8}

Untuk melaksanakan tugas pengaturan sebagaimana dimaksud dalam Pasal 6, OJK mempunyai wewenang

a. menetapkan peraturan pelaksanaan Undang-Undang ini;

b. menetapkan peraturan perundangundangan di sektor jasa keuangan;

c. menetapkan peraturan dan keputusan OJK;

d. menetapkan peraturan mengenai pengawasan di sektor jasa keuangan;

e. menetapkan kebijakan mengenai pelaksanaan tugas OJK;

f. menetapkan peraturan mengenai tata cara penetapan perintah tertulis terhadap Lembaga Jasa Keuangan dan pihak tertentu;

g. menetapkan peraturan mengenai tata cara penetapan pengelola statuter pada Lembaga Jasa Keuangan;

h. menetapkan struktur organisasi dan infrastruktur, serta mengelola, memelihara, dan menatausahakan kekayaan dan kewajiban; dan i. menetapkan peraturan mengenai tata cara pengenaan sanksi sesuai dengan ketentuan peraturan perundangundangan di sektor jasa keuangan.

\section{Pasal 9}

Untuk melaksanakan tugas pengawasan sebagaimana dimaksud dalam Pasal 6, OJK mempunyai wewenang:

a. menetapkan kebijakan operasional pengawasan terhadap kegiatan jasa keuangan;

b. mengawasi pelaksanaan tugas pengawasan yang dilaksanakan oleh Kepala Eksekutif;

c. melakukan pengawasan, pemeriksaan, penyidikan, perlindungan Konsumen, dan tindakan lain terhadap Lembaga Jasa Keuangan, pelaku, dan/atau penunjang kegiatan jasa keuangan sebagaimana dimaksud dalam peraturan perundang-undangan di sektor jasa keuangan;

d. memberikan perintah tertulis kepada Lembaga Jasa Keuangan dan/atau pihak tertentu;

e. melakukan penunjukan pengelola statuter;

f. menetapkan penggunaan pengelola statuter;

g. menetapkan sanksi administratif terhadap pihak yang melakukan pelanggaran terhadap peraturan perundang-undangan di sektor jasa keuangan; dan

h. memberikan dan/atau mencabut:

1. izin usaha;

2. izin orang perseorangan;

3. efektifnya pernyataan pendaftaran;

4. surat tanda terdaftar;

5. persetujuan melakukan kegiatan usaha;

6. pengesahan;

7. persetujuan atau penetapan pembubaran; dan

8. penetapan lain, sebagaimana dimaksud dalam peraturan 
perundang-undangan di sektor jasa keuangan.”

Demikian diatas telah di sampaikan Tujuan, Tugas, Fungsi dan Wewenang dari ketiga lembaga yaitu Bank Indonesia, BAPEPAM-LK dan OJK maka dari kewenangan tersebut kita dapat melihat bahwa Pengawasan pasar modal sejatinya dilakukan oleh BAPEPAM-LK yang kemudian digantikan oleh OJK sebagai lembaga baru yang menerima hampir semua kewenangan BAPEPAM-LK serta ditambah beberapa kewenangan lainnya, OJK merupakan lembaga yang independen dalam melaksanakan tugas dan wewenangnya, bebas dari campur tangan pihak lain, kecuali untuk hal-hal yang secara tegas diatur dalam UndangUndang ini ${ }^{4}$.

Sedangkan Bank Indonesia hanya mengawasi sisi tertentu yang terkait dengan Bank karena dalam pasar modal juga ada andil perbankan dalam menjalankan beberapa sisi dari pasar modal.

Bila dilihat dari kewenangan masing masing antara Bank Indonesia dan OJK maka sebenarnya ada tumpang tindih kewenangan yang berpotensi menimbulkan disharmonisasi karena adanya distribusi kewenanan ganda, namun hal ini hanya sekesar potensi bila dapat di maintenance dengan baik.

Melihat hubungan ini sudah ada kesepahaman yang resmi telah di sampaikan oleh OJK menganai hubungan OJK dengan Bank Indonesia yaitu, "Menurut Pasal 39 UU Nomor 21 tahun 2011, OJK bisa berkoordinasi dengan BI dalam pengaturan dan pengawasan perbankan, misalnya, dalam hal kewajiban pemenuhan modal minimum bank ataupun kebijakan penerimaan dana dari luar negeri, penerimaan dana

\footnotetext{
${ }^{4}$ Pasal 2, Undang undang 21 tahun 2011 tentang

Otoritas Jasa Keuangan
}

valuta asing maupun pinjaman komersial luar negeri. Berikut ini berbagai bentuk nyata sinergi antara BI dan $\mathrm{OJK}^{5}$ :

a. OJK berkoordinasi dengan BI dalam membuat peraturan pengawasan di bidang perbankan. Hal tersebut merupakan salah satu contoh bahwa kesatuan langkah kedua lembaga harus selalu ada. Kombinasi kompetensi dari personel masing-masing lembaga dimaksud akan mampu menciptakan suatu tatanan aturan perbankan yang lebih sempurna. Penyamaan persepsi antara BI dan OJK dalam menentukan kebijakan atau pengaturan perbankan akan menghasilkan tatanan sistem perbankan yang tangguh dalam menghadapi segala kondisi;

b. Tidak hanya dalam pembuatan aturan, BI dan OJK juga harus terintegrasi dalam tukar menukar informasi perbankan. Melalui penggabungan sistem informasi ini, BI dan OJK akan lebih mudah mengakses informasi perbankan yang disediakan masing-masing lembaga setiap saat (timely basis). Informasi strategis yang dimiliki masing-masing lembaga dan aksesibilitas yang mudah sangat menunjang efektivitas pelaksanaan tugas; c. Dalam rangka pemeriksaan bank, BI dan OJK juga terus melakukan hubungan timbal balik. BI dalam kondisi tertentu akan melakukan pemeriksaan khusus terhadap bank setelah berkoordinasi dengan OJK. Begitupun sebaliknya, dalam hal OJK mengidentifikasikan bank tertentu mengalami kondisi yang memburuk maka OJK akan segera menginformasikan kepada BI. Kerja sama reciprocal dimaksud sangat bermanfaat untuk mengantisipasi dampak sistemik negatif dari suatu kondisi perbankan. Dengan kerja sama itu pula tindakan

\footnotetext{
${ }^{5}$ https://www.ojk.go.id/id/Pages/FAQ-

Otoritas-Jasa-Keuangan.aspx
} 
penanganan yang tepat dapat diambil dengan cepat."

\section{PENUTUP}

Kewenangan yang diberikan pada OJK begitu luas, perlu diperhatikan dan dipastikan bawa setiap kewenangan tersebut dapat saling bersinergi, berintergasi dan saling melengkapi, namun jika ternyata ada hal-hal yang dianggap sebagai suatu hal yang tumpeng tindih maka dilakukan penyesuaian yang mana hal inilah yang membuat perlu adanya koordinator pada masing-masing lini atau bidang dalam penyelenggaraan negara untuk memastikan distribusi atas kekuasaan dan kewenangan menimbulkan suatu keharmonisan dan dapat menjamin terciptanya kepastian hukum yang baik.

Pengaturan secara jelas antara tujan, tugas, fungsi, kewenangan dan titik berat kewenangan tersebut merupakan suatu langkah yang sangat penting dan harus di perhatikan dengan seksama untuk menumbuhkan Pasar Modal yang kuat, transparan, bersinergi, baik, aman, memiliki kepastian hukum dari regulasi yang dibuat secara profesional dan akuntabel.

Demikian pembahasan terkait pengawas pasar modal yang perlu untuk dipahami Tujuan, Fungsi, Tugas dan wewenangnya.

\section{DAFTAR PUSTAKA}

\section{Buku}

Robert Gilpin dan Jean M. Gilpin. 2001. Global Political Economy Understanding the International Economic Order. New Jersey: Prineeton University Press.

Sahrasad, Herdi. 2009. Centurygate: Refleksi Ekonomi-Politik Skandal Bank Century. Jakarta: Freedom
Foundation, Yayasan Indonesia Baru dan Lingkar Studi Islam dan Kebudayaan.

\section{Internet}

Tony Rodyanto, Pengawasan Terintegrasi Lembaga Jasa Keuangan (Suatu Tinjauan Umum) (On-line) dapat diunduh di: http: / / tonyrodyanto.wordpress.com /2014/09/08/pengawasanterintegrasi-lembaga-jasa-keuangansuatu-tinjauan-umum/.

"Mengawasi Konglomerasi Industri Keuangan" (On-line) dapat diunduh di:

http://www.businessnews.co.id/eko nomi-bisnis / mengawasi-

konglomerasi-industrikeuangan.php.

"Awasi Konglomerasi Perbankan", dapat diunduh di: http: / / sinarharapan.co/news/read/ 140421086/Awasi-KonglomerasiPerbankan-span-span-.

-Regulasi Otoritas Jasa Keuangan (On-line) dapat diunduh di: http:/ /ojk.go.id/peraturan-otoritasjasa-keuangan-tentang-penerapantata-kelola-terintegrasi-bagikonglomerasi-keuangan.

“Juni 2015 OJK Mulai Mengawasi Konglomerasi Bank-Bank Besar" (On-line) dapat diunduh di: http://brita.indo.com/2014/09/juni -2015-ojk-mulai-awasikonglomerasi-bank-bank-besarmerdeka-com/.

\section{Peraturan Peundang-undangan}

Undang-Undang Nomor 10 Tahu 1998 tentang Perbankan

Peraturan Otoritas Jasa Keuangan Nomor 17/POJK.03/2014 tentang Penerap- 
an Manajemen Risiko Terintegrasi bagi Konglomerasi Keuangan.

Peraturan Otoritas Jasa Keuangan Nomor 18/POJK.03/2014 tentang
Penerapan Tata Kelola Terintegrasi bagi Konglomerasi Keuangan 